people from 'the university'. The prioritisation of basic physical care, paperwork and health and safety issues highlights concerns about the 'industrialisation' of the care process, where the person with dementia may be dealt with as a set of tasks rather than as an individual with their own values and preferences. Although conclusions such as 'the successful implementation of psychological interventions is also a question of resources and time, ${ }^{13}$ and 'psychosocial interventions must be implemented in person-centred care ${ }^{13}$ are nothing new, they are needed here to provide a proper context.

\section{Making psychosocial interventions work}

Echoing the themes for future research in the INTERDEM manifesto, Lawrence et al's study provides a synthesis of evidence and a better understanding of the active components of complex interventions. ${ }^{2}$ Despite this, it tells us little about which specific interventions might work, their comparative effects, or how they could be implemented in practice. Thus in some ways the results may be more useful as a contribution both to the theory and development of new interventions, or for the modification of existing interventions to enhance their utility. As stated, there is a need for future RCTs to include qualitative work to better understand how interventions work. But even for psychosocial interventions shown to be both clinically effective and cost effective, there are a number of obstacles to getting them into widespread practice. Many interventions have either no practice manual or one that is so poorly specified that the intervention cannot be reliably replicated in practice. Training may be hard to access or not widely available. Even with a manual and training, the lead researchers may lose interest and move on to other projects, particularly if no resources for an implementation study are forthcoming. In contrast, drug companies devote very considerable resources not only to drug development and clinical trials, but also to publicising the study results, and to promoting the use of the drugs in practice. However, whereas drugs have a daily cost, the expertise derived from manuals and training can be used on a whole series of patients. The new generation of psychosocial interventions, a number of which have been shown to be effective in practice, can often provide excellent value. There is a pressing need for further research to promote implementation in practice.
Martin Orrell, University College London, 67-73 Riding House Street, London WC1E 6BT, UK. Email: m.orrell@ucl.ac.uk

First received 8 Mar 2012, accepted 21 Jun 2012

\section{References}

1 Orrell M, Woods B. Tacrine and psychological therapies in dementia no contest? Int J Geriatr Psychiatry 1996; 11: 189-92.

2 Moniz-Cook E, Vernooij-Dassen M, Woods B, Orrell M. Psychosocial interventions in dementia care research: the INTERDEM Manifesto. Aging Ment Health 2011; 15: 283-90.

3 Medical Research Council. Developing and Evaluating Complex Interventions: New Guidance. MRC, 2008.

4 Spector A, Thorgrimsen L, Woods B, Royan L, Davies S, Butterworth M, et al. Efficacy of an evidence-based cognitive stimulation therapy programme for people with dementia. Randomised controlled trial. Br J Psychiatry 2003; 183: $248-54$.

5 Graff M, Vernooij-Dassen M, Thijssen M, Dekker J, Hoefnagels WH, Rikkert MG. Community based occupational therapy for patients with dementia and their care givers: randomised controlled trial. BMJ 2006; 333: 1196.

6 Teri L, Gibbons L, McCurry S, Logsdon R, Buchner M, Barlow W, et al. Exercise plus behavioral management in patients with Alzheimer disease: a randomized controlled trial. JAMA 2003; 290: 2015-22.

7 Livingston G, Johnston K, Katona C, Paton J, Lyketsos C. Systematic review of psychological approaches to the management of neuropsychiatric symptoms of dementia. Am J Psychiatry 2005; 162: 1996-2021.

8 Prince M, Bryce R, Ferri C. World Alzheimer Report 2011: The Benefits of Early Diagnosis and Intervention. Alzheimer's Disease International, 2011.

9 Olazarán J, Reisberg B, Clare L, Cruz I, Peña-Casanova J, del Ser T, et al. Nonpharmacological therapies in Alzheimer's disease: a systematic review of efficacy. Dement Geriatr Cognitive Dis 2010; 30: 161-78.

10 Spijker A, Vernooij-Dassen M, Vasse E, Adang E, Wollersheim H, Grol R, et al., Effectiveness of non-pharmacological interventions in delaying the institutionalization of patients with dementia: a meta-analysis. J Am Geriatr SOC 2008; 56: 1116-28.

11 Mittelman M, Haley W, Clay O, Roth D. Improving caregiver well-being delays nursing home placement of patients with Alzheimer disease. Neurology 2006; 67: 1592-9.

12 Vernooij-Dassen M, Vasse E, Zuidema S, Cohen-Mansfield J, Moyle W. Psychosocial interventions for dementia patients in long-term care. Int Psychogeriatr 2010; 22: 1121-8.

13 Lawrence V, Fossey J, Ballard C, Moniz-Cook E, Murray J. Improving quality of life for people with dementia in care homes: making psychosocial interventions work. Br J Psychiatry 2012; 201: 344-51.

\title{
Southern blot
}

\section{Nick Craddock}

Named after its UK inventor, Ed Southern, a 'southern blot' is a laboratory method that identifies specific types of sequence variant in DNA. It revolutionised molecular genetics in the 1980s by making it possible to produce systematic maps of genetic variation in health and disease. The pace of progress in molecular genetics was such that Southern blots were rapidly superseded by faster polymerase chain reaction (PCR)-based technologies that use much less DNA. They have been rarely used over recent years in DNA work, although related approaches are used with work on RNA (so-called 'northern blots') and proteins (so-called 'western blots'). 